\title{
Business and Delays in Port Reform in Brazil
}

\author{
Negócios e Atrasos na Política Portuária no Brasil
}

MAHRUKH DOCTOR*

RESUMO: O caso da reforma da modernização portuária no Brasil resume os problemas que os reformadores brasileiros enfrentam. Embora a legislação da reforma tenha sido aprovada em 1993 (Lei 8.630/93), ainda existem muitos obstáculos para a plena implementação. Este artigo concentra-se em como as atitudes e ações dos negócios adiaram a reforma e demonstra como as empresas são incapazes de contribuir para a implementação da reforma devido a obstáculos institucionais e problemas de ação coletiva. Em seguida, sugere um mecanismo para superar essas dificuldades; especificamente, examina a evolução do corporativismo e o valor da construção de comunidades políticas unidas e democráticas que atendam às necessidades de cada setor. $\mathrm{O}$ trabalho empírico é complementado com uma combinação incomum de três abordagens teóricas para explicar a economia política da modernização institucional: economia institucional desenvolvida por Douglass North, lógica da ação coletiva elaborada por Mancur Olson e análise de redes políticas desenvolvida por Marsh e Rhodes, Jordan e Richardson.

PALAVRAS-CHAVE: Transportes; portos; reforma econômica.

ABSTRTACT: The case of port modernization reform in Brazil encapsules the problems Brazilian reformers face. Although reform legislation was passed in 1993 (Law 8.630/93), many obstacles remain for full implementation of its provision. This article focuses on how business attitudes and actions deferred reform, and demonstrates how business is unable to contribute to reform implementation because of institutional obstacles and collective action problems. It then suggests a mechanism to overcoming these difficulties; specifically, it examines the evolution of corporatism and the value of constructing democratic close-knit policy communities meeting the needs of each sector. The empirical work is complemented with an unusual combination of three theoretical approaches to explain the political economy of institutional modernization: institutional economics as developed by Douglass North, the logic of collective action as elaborated by Mancur Olson, and policy network analysis as developed by Marsh and Rhodes, Jordan and Richardson.

KEYWORDS: Transportalin; ports; economic reform.

JEL Classification: P11; R10.

\footnotetext{
* Research Fellow in International Political Economy Centre for Brazilian Studies, University of Oxford. e-mail: mahrukh.doctor@brazil.ox.ac.uk; Orcid: 0000-0001-8221-2522.
} 


\section{INTRODUCTION}

This article analyses the case of port modernization reform in Brazil and explains why business action and influence varies at different stages of the reform process. Specifically, it accounts for business' exceptional role in policy formulation, but subsequent weak performance in contributing to and monitoring reform implementation. The case is particularly interesting because it encapsules the problems Brazilian reformers face elsewhere in the economic and political liberalization process and throws light on the incrementalist approach to reform, typical in Brazil. It also demonstrates how in the context of the dismantling of the developmentalist State and the achievement of economic stabilization, corporatist institutions hamper business articulation, interest representation and profits.

This article focuses on how business attitudes and actions deferred reform, but it is based on a wider and extensive study of the formulation, adoption and implementation of the Port Modernization Law (Law 8.630/93). It shows how business is unable to sustain pressure to ensure reform implementation because of institutional obstacles and collective action problems, and then suggests possible approaches to overcoming these difficulties. It explores the options open to Brazil with respect to adapting corporatist institutions to a democratic and increasingly open market economy. Specifically, it examines the evolution of corporatism and the value of developing a new associational landscape, with the construction of both close-knit policy communities meeting the needs of each sector and a broader peak association representing cross-sectoral business interests. Institutional constraints suggest a progressive pluralization of corporatism, with increasing democratization of societal input into policy-making, rather than a complete abandonment of the corporatist institutional structure instituted by president Vargas in the 1930s and 1940s. There appears to be positive potential for the gradual evolution of corporatism. Conversely, success would be less likely should policy-makers decide to introduce systemic change via a comprehensive overhaul of economic regimes and rules of the game.

The article has five sections: (i) introduction to the analytical framework; (ii) brief comments on the situation in Brazilian ports and the impact of business lobbying; (iii) how corporatist sectoralization and business disunity obstruct reform implementation; (iv) mechanisms for overcoming business difficulties, specifically, the creation of policy networks to build sectoral strength; and (v) some concluding remarks.

The theoretical and empirical analysis appears side-by-side throughout the article, which applies an unusual combination of three theoretical approaches that surprisingly complement each other: institutional economics as developed by Douglas North, the logic of collective action as elaborated by Mancur Olson, and policy network analysis as developed by Marsh and Rhodes, Jordan and Richardson. ${ }^{1}$ This

\footnotetext{
${ }^{1}$ See bibliography for full references of these authors' works.
} 
combination enriches the analysis and is justified, given that any single approach cannot adequately explain the outcomes of the Brazilian political economy.

Institutional analysis focuses on the impact of institutions on policy design and outcomes; in other words, institutions may or may not be supportive of reform. North's analysis incorporates the traditional political science view of institutions as formal rules and informal constraints on economic and political actors, but goes beyond this to claim that institutions (and not just societal actors or organizations) can have goals. ${ }^{2}$ Institutions provide stability, but must include mechanisms to allow society to explore alternatives to solving new problems and to respond to new issues. "It is essential to have rules that eliminate not only failed economic organizations, but failed political organizations as well [...] that the institutional structure not only rewards successes, but also vetoes the survival of maladapted parts of the organizational structure, [...]" ${ }^{3}$ However, inefficient institutions survive by relying on entrenched interests that oppose reform. In particular, this article demonstrates how corporatist institutions influence the representation of interests in Brazil and shape the expectations and behavior of all political and economic actors including labor, business, government, legislators, bureaucrats and the media. However, institutional analysis alone is insufficient to explain how groups organize to replace and modernize institutions.

The logic of collective action model focuses on the rationale behind the organization of groups, and how this determines their power and impact on the policy process. The simple Olsonian argument is that the effectiveness of a group is not a function of its degree of support in society, but rather depends on its ability to organize itself to attain a collective good. Broadly speaking, the business community as a whole, or any large section thereof (for example, exporters), is not a small privileged group, and therefore faces the collective action problems typical of any large group (Olson, 1965). The logic of collective action leads to the expectation that interests remain latent unless a so-called political entrepreneur succeeds in making co-operation rational and minimizes the problem of free-riders. Given the dynamics and difficulties of group organization, normally organizing small groups based on "special interests" is much easier. Another crucial point in the model is that "widespread and enthusiastic agreement on a political goal may give rise to no contribution at all" (Moe, 1980), because nobody has a disproportionate gain from or a special interest in organizing for it. However, the model focuses on the formation of groups, but not on their survival and influence over policy. It underplays the impact of the State on organizing interests, and the role of institutions in the translation of policy preferences into policy outcomes.

The policy network approach emphasizes the importance of developing ongoing close links between business and State actors in a democratic context to

\footnotetext{
${ }^{2}$ North's (1990) view is that the main goal of institutions is to reduce transaction costs, by reducing uncertainty, increasing available information and guaranteeing property rights.

${ }^{3}$ North (1990), p. 81, italics are my words.
} 
maximize the match between policy intentions and outcomes. Policy network analysis represents a new approach to business-State relations in Brazil, notwithstanding hints in the literature referring to iron triangles and bureaucratic rings. The approach, predominantly developed in Britain to study interest group intermediation, emphasizes the importance of the continuity of relations between interest groups and government departments, in an essentially pluralist context. It focuses on the meso-level of policy-making, usually looking into the relationship that develops between political institutions and interest groups. The article compares the nature of the different types of networks operating in the Brazilian port sector, and demonstrates how old style corporatist networks (including bureaucratic rings) differ from modern policy networks. One of the approach's weaknesses is that it fails to consider the difficulty of forming and maintaining a policy community in times of policy change. All the same, it suggests a useful means of analyzing the possible evolution of corporatism in Brazil.

In terms of methodology, the research project was based on written questionnaires and over seventy open-ended interviews (lasting between one and three hours) with most of the major participants in the process, including business and labor leaders, policy-makers in the legislature and executive, port administrators, a labor court judge, and senior journalists (the media played a key role).

A final comment before analyzing the specific case of port modernization in Brazil: in developing countries, bureaucratic control over distribution of subsidies gives industrialists every incentive to focus on individual interests and free ride rather than investing effort in developing a collective agenda. In this context, it becomes necessary to develop institutions that minimize the conflict between social and individual interests. Initially, corporatism fulfilled this purpose, but by the mid 1980s, democratization, globalization and liberalization exposed the urgent need to overhaul corporatism. However, institutional modernization is difficult when opposition originates in vested interests, where a secure, closed and established network between officials and private interests exist. In such cases, reform and economic transformation is often delayed, if not aborted.

\section{BUSINESS AS SPUR TO PORT REFORM LEGISLATION}

By 1990, inefficient infrastructure, inadequate institutional arrangements regarding port labor, administration and operation, and neglected investment needs lay at the heart of the high cost and low productivity of Brazilian ports. Although a number of factors influenced the formulation and approval of the Port Modernization Law, Law 8.630/93 in February 1993, the contribution of business lobbying stands out as the central factor, indispensable to the successful formulation of the policy. Ação Empresarial Integrada (AEI), as the business lobby was known, was unique in Brazilian history, because it was the first time business formally organized a unified lobbying network to achieve a specific policy change via democratic means. 
Until the late 1980s, in line with Olsonian predictions of group behavior, portusers, a dispersed group with few strong motivations for collective action, remained a latent interest group. ${ }^{4}$ Business assets were more flexible and seldom tied to one area of activity. An effective port reform lobby was organized only after the impact of globalization, an end to ISI and the opening of the economy forced industry to focus on competitiveness. Again in line with Olsonian predictions, the few large industrialists with a vital stake in reducing port costs, or expecting a disproportionate gain, took the initiative in organizing the port reform lobby (this included steel exporters, like Jorge Gerdau, and private terminal owners). The importance of a critical mass of individuals willing to bear the initial costs of organizing collective action was crucial. This active group of "winners" could then overcome the apathy of the rest.

AEI's lobbying success may lie in its unusual structure - a peak association (which increased the representativeness of its position) that operated like a network (which increased the flexibility of its action). At its height, it included 52 business associations and federations. ${ }^{5}$ In addition to representatives from the major exporting industries and large private terminal owners, entrepreneurs eager to exploit the market's demand for importing capital and consumer goods also gave low-key support. AEI's inner core of six or seven businessmen operated like a strategic nucleus and undertook all negotiations and lobbying on behalf of business. Moreover, it was willing to test new approaches to lobbying, based on building a network of pro-reform actors within the State. AEI convinced policy-makers in the executive and legislature of the importance of port reform and successfully presented its case to the media and the public. Most remarkably, it managed to convince labor peak associations that reform was necessary and therefore to withhold their explicit support from port unions.

Table I: Sectoral Origin of AEI Members (May 1992)

\begin{tabular}{ll}
\hline Confederations and Federations (industry \& commerce) & 10 \\
Mining, Steel \& Other Metals & 9 \\
Machines, Equipment \& Transport Materials & 6 \\
Chemicals, Textiles, Paper \& Others & 9 \\
Food \& Agriculture & 9 \\
Shipping \& Port-Related & 5 \\
Exports & 2 \\
\hline
\end{tabular}

Source: AEI, 1992

\footnotetext{
${ }^{4}$ This argument is reinforced by the fact that capitalists in general find it very difficult to co-operate since their principal relationship to each other is governed by competition.

${ }^{5}$ Although the federations did not actively participate in lobbying Congress, they lent their support to $\mathrm{AEI}$ and allowed it to speak in the name of most business. This allowed AEI to rely on the moral support of the official corporatist associations, augmenting its legitimacy in the eyes of legislators and society.
} 
Business also avoided blaming the government directly for the situation in ports and focused its efforts on three demands:

1. End of the labour union monopoly;

2. Liberty of the private terminals to handle third party cargoes; and

3. Privatization of port services and restructuring of ports in the near-term.

A key AEI member (interview July 1994) emphasized the importance of the broad consensus among business, and provided useful insight when he acknowledged that:

"Businessmen at best had a general idea of the inefficiencies of the Brazilian port system. They also knew that change would be beneficial, but were unsure about what exactly would serve their best interest. This is the big secret of our unity. We appeared monolithic; we acted unified because the majority of businessmen did not understand the system. They left port reform in our hands to do as we thought best."

Interviews revealed numerous positive evaluations of business unity and lobbying performance. Port union leaders unanimously praised AEI's organizational effort. Here is one example: ${ }^{6}$

"It is the most competent lobby ever seen in the country. Business made excellent use of the media, maintained a constant presence in Congress, employed competent staff and pursued a rigorous follow-up on all points."

Business consensus was most remarkable given the typical businessman's attitude that is self-regarding, short-term and competitive vis-à-vis other businessmen. Business interviewees repeatedly stated that business refused to give up in the face of unmotivated governments, lethargic bureaucracies and insular labour unions. Although lack of general business understanding and commitment to the finer points of the reform was not a problem during policy formulation (indeed some claimed it was an advantage), it would hamper pro-reform actors in the implementation process. As one business interviewee (October 1997) commented, "maintaining solidarity is very difficult, when business commitment dissolves with the first threat of a strike."

${ }^{6}$ Interview in Santos in May 1994. 
Table II: Evaluation of Lobbying Success of Business and Labor Groups

\begin{tabular}{lcc}
\hline Option & Business (port users) & Labor (port unions) \\
\hline Very Successful & $18 \%$ & $4 \%$ \\
Successful & $62 \%$ & $29 \%$ \\
Little Success & $20 \%$ & $58 \%$ \\
Unsuccessful & 0 & $9 \%$ \\
\hline
\end{tabular}

Source: responses to author's written questionnaire. 45 respondees included business, labor, port administrators and federal legislators.

Finally, in the context of democratization and liberalization, AEI demonstrated that business understood the need for a re-evaluation of past business strategies and a new approach to business-State relations, based on more open interaction and reduced State intervention.

\begin{tabular}{lc} 
Table III: Average of Tons Loaded Per Man/Hour (1990) \\
\hline Kobe & 184 \\
New Orleans & 120 \\
Rotterdam & 70 \\
Hamburg & 60 \\
Santos and Rio & 30 \\
\hline
\end{tabular}

Table IV: Loading of Non-Plane Steel Products (1989)

\begin{tabular}{lcc}
\hline Port & Average Cost (US\$/Ton) & Size of Work Team (land + ship) \\
\hline Antwerp & 4.50 & $24+18=42$ \\
Hamburg & 5.90 & $21+15=36$ \\
Rotterdam & 7.20 & $18+12=30$ \\
New Orleans & 10.00 & $24+15=39$ \\
Vitória & $12-15$ & \\
Rio de Janeiro & $18-23$ & \\
Santos & $35-37$ & \\
\hline
\end{tabular}

Source: ASP, 1989

In addition to strong, unified and effective business lobbying, another four key factors acted as spurs to reform: (i) the effect of globalization, trade liberalization and systemic competitiveness (Custo Brasil) on the Brazilian economy; (ii) the impact of the disastrous situation in Brazilian ports on the efficiency of cargo handling; (iii) the experience of other country's with port reform, especially port labor regime reform; and (iv) strong media interest which increased public awareness of 
the causes for the inefficiency of Brazilian ports. Ports were plagued by crumbling equipment and infrastructure, out-dated technology, the government's arbitrary and precarious system of taxation, entangled port bureaucracy, inefficient customs procedures, as well as an unproductive labor regime. However, most businessmen admitted that before the liberalization of the economy, end of numerous subsidies, downturn in the domestic market and noticeable impact of globalisation, businesses had paid little attention to high port costs.

Table V: Principal Problems in Brazilian Ports (pre-1993)

\begin{tabular}{lc}
\hline Port union monopoly* & $67 \%$ \\
Inadequate management authority & $47 \%$ \\
Low productivity of port labor & $40 \%$ \\
Organizational density & $40 \%$ \\
Lack of capital-intensive cargo-handling systems & $31 \%$ \\
Poor maintenance of port equipment & $29 \%$ \\
Customs procedures & $22 \%$ \\
Overlapping rules & $13 \%$ \\
Poor links to international distribution chains & $8 \%$ \\
Inefficient utilization of cargo-handling systems & $8 \%$ \\
\hline Source: 45 questionnaire responses. Each respondent indicated the top three problems \\
in Brazilian ports before Law 8630/93. \\
* 93\% of business respondents indicated the union monopoly as one of the worst problems.
\end{tabular}

It is only after 1990 that port costs and inefficiencies noticeably damaged the competitiveness of general cargo (i.e. non-bulk goods), or the very area of exports that dealt with manufactured goods with a higher value added component. Although general cargo represents only a quarter of Brazilian exports, they stem from crucial sectors that affect the competitiveness and development of the economy. Although the problems were recognized and new investments were urgently needed, business interviewees noted the risks of investing in ports under the prevailing port institutional structure, because of uncertainly about the government's commitment to improving basic infrastructure and streamlining bureaucratic procedures and business' inability to independently determine its labor requirements.

\section{BUSINESS AS OBSTACLE TO PORT REFORM IMPLEMENTATION}

Ironically, business was not only the champion of port reform, but also one of the main agents to create obstacles in the path of reform implementation. Its share of the blame goes beyond the ill-advised action of AEI leaders to disband in 1993, immediately after port reform received presidential approval, thus presenting port workers with an opportunity to reclaim lost ground. Workers gambled on uninformed port-users, the ambivalent position of ship owners and the satisfaction of 
private terminal owners. Union leaders correctly surmised that most port-users would not monitor progress made on implementation; that ship owners would avoid confrontation on board their ships; that private terminal owners' would lose the motivation to fight for the full implementation of all aspects of the new law. ${ }^{7}$ But the crucial point is: what gave union leaders this confidence that business consensus would collapse and that the will to fight for implementation would dissipate?

A number of conjunctural factors militated against early implementation of reform, including (i) changes in government priorities (Itamar Franco was less interested in the liberalization agenda of the Collor government, and Cardoso was uncomfortable with the wider implications of doing away with corporatist privileges) and lack of government resources; and (ii) swings in economic growth and business conditions (stabilization under the Real Plan on the one hand meant that many businesses switched their focus back to the domestic market, and on the other hand, many businesses preferred to obstruct or minimize growing competition from relatively cheap imports). While these factors had a decisive impact on reform outcomes, research showed that the corporatist networks in ports relied on institutional rigidities to block reform implementation. The research project on which this article is based found that the corporatist institutional context within which interest groups operated strongly influenced their strategies, attitudes and behavior, which in turn impacted the chances for reform success. This article acknowledges the importance of, but does not spotlight the conjunctural factors, instead it focuses on how corporatist institutions shape business attitudes and collective action problems inhibit business action.

Corporatist Sectoralization: Corporatism refers to the formal structure of interest representation imposed by the State and used to incorporate the groups emerging from the incipient industrialization and modernization process. The specific features of the corporatist structure include singular, compulsory, hierarchical and functionally differentiated categories organized into representative associations granted exclusive control over group resources and a representational monopoly vis-à-vis their interaction with the State. ${ }^{8}$ Although in theory, corporatism applies to both business and labor, in practice it marginalized labor - the great exception is the corporatist network that developed in ports between port labor unions and the port administrative bureaucracy attached to the dock companies and federal ministries. Effectively, the corporatist network in ports is a "bureaucratic ring" with labor instead of business representatives.

In Brazil, State corporatism and interventionism encouraged businesses to present their demands individually, by focusing on particularistic paths of influence to

\footnotetext{
${ }^{7}$ The law authorised private terminals to handle third party cargoes, thus granting the main demand of their association, ABTP.

${ }^{8}$ See Schmitter (1971; 1974), Diniz and Boschi (1978), Diniz (1993), Boschi (1991), Cardoso (1986), Cawson (1986), Cohen (1989), Evans (1979; 1995), O’Donnell (1977), and Tavares de Almeida (1989) for good descriptions and analysis of corporatism in general and in Brazil.
} 
State actors, despite nominal membership of corporatist-monopolistic associations. The benefits of adhering to corporatist expectations are assimilated at all levels, and provide the context within which policies are designed and then implemented. In the case of ports, corporatist institutions award privileges and foster opposition to reform in port labor; create sources of power among bureaucrats and engender obstruction to reforms when these powers are withdrawn; and fragment business interests and generate apathy to the consequences of reform among businesspeople.

The government is aware that port reform will stagnate unless corporatist privileges are withdrawn, but it is reluctant to address the general issue of institutional reform and unwilling to cut into the powers granted via the Consolidation of Labor Laws (CLT), the heart of corporatist legislation. ${ }^{9}$ Corporatism brings workers and bureaucrats closer to their respective groups, but engenders disunity and apathy in a fragmented business class. ${ }^{10}$ Thus, whereas labor and bureaucratic opposition to port reform required active obstruction, in the case of business, passive neglect ensured that corporatist institutions successfully blocked reform. Business interviewees repeatedly acknowledged that apathy was the result of years of:

- economic uncertainty and survival concerns;

- reliance on State subsidies and incentives, creating a culture of dependenceand paternalistic interaction with State institutions; and

- inadequate consultation of the membership base and the politicized manage-ment of the corporatist associations.

- More generally, corporatism was popular among industrialists, because itmaintained established patterns in capital-labor relations, granted access to substantial resources via the "Sistema $S$ " (apprentice and training programs), and provided a guarantee against radical changes. Corporatist institutions provided some extra reassurance in a country beset with social, political and economic problems. Moreover, business did not rely on corporatist associations alone, precisely because it was aware of the weaknesses inherent in corporatist groups and methods of interest representation. The private sector often benefited from a parallel representative structure, which operated outside the confines of corporatist legislation.

Brazilian corporatism failed to create strong business class solidarity and disallowed the formation of a single peak association. The State ensured that business people, locked into monopolistic structures, were given few opportunities to orga-

\footnotetext{
${ }^{9}$ Curiously, the daily-hire port union monopoly is based on privileges awarded under the CLT, although port workers formally fall outside the CLT (this is because the CLT does not apply to avulsos/daily-hire workers).

${ }^{10}$ Perhaps the worst consequence of embedded corporatism is the evident apathy it generates. Thus, for example, when the capital moved, the CNI did not find it necessary to move its headquarters to Brasília. This only occurred in late 1996, when the new president of the confederation, Fernando Bezerra (who is a senator, and therefore, spends most of his time in Brasilia), insisted that industrialists cannot hope to monitor developments in the capital and influence policy without a permanent presence in Brasília.
} 
nize and co-ordinate their activities. Business seldom bothers to make collective protests against uncompetitive business or regulatory practices. Business interviewees did not remark on the contradiction inherent in the federal government's withdrawal from port operations, but right to nominate the head of the new port authority. Instead, business uses the Port Authority Councils (CAPs) as a forum for the discussion of capital-labor issues, with the government as mediator in the corporatist tradition.

However, business attitudes appear to be changing. The younger generation of businesspeople often refers to corporatist federations as "irrelevant, anachronistic and comatose" institutions. In June 1996, Ricardo Semler wrote:

"FIESP has no reason to exist any longer. Not in its classical format. [...] All organizations of this type (i.e. agglomerating business interests) are bureaucratized to the point of inactivity; they are cellars facilitating influence bargaining and corruption, and end up attracting petty interests and figures of little importance." ${ }^{11}$

Several businessmen commonly referred to their associations and federations as "parasites" and "dinosaurs", that they "represent diluted interests and operate like grand money spending machines, and serve to inflate the egos and pockets of their directors". ${ }^{12}$ One claimed, "doctrine and philosophy are not as important as the struggle for power within the FIESP. Unimportant businessmen often strive for the most important positions within the federation".

Although corporatism hampers business collective action during policy formulation, it is policy implementation that highlights corporatism's truly debilitating affect on business action and unity. Corporatist traditions accentuate personalistic and particularist interaction between business and State actors. Networks emerge along the lines of closed "bureaucratic rings" (these will be analyzed later in the article). This usually assures some degree of access to large firms, but leaves small and medium sized enterprises (SMEs) with few options. Thus, corporatism reinforces sectoral and size-based divisions, which further reduce business unity and ability to put pressure on State actors for policy implementation. An excellent illustration of the problem: the port-user committee, COMUS, of the Commercial Association of São Paulo (ACSP) conducted a survey in May 1994. It sent out 1000 survey forms to small and medium-sized export businesses and received only 81 responses. $95 \%$ of these firms said that they did not follow progress in the implementation of Law 8.630/93, a law that could directly enhance their competitiveness in international markets and increase their profits. Similarly, there are few protests

\footnotetext{
${ }^{11}$ Signed article by Ricardo Semler in Folha de S. Paulo, 21 June 1996. Semler is a past director of FIESP and a vocal critic of business corporatism.

12 These comments are from a number of business interviewees in São Paulo, Rio de Janeiro and Porto Alegre.
} 
from port-users affected by the cartel-like practices of the private sector warehousing firms in the Santos area (warehousing firms argue their case based on the legal requirement that they charge clients at least as much as the state-owned dock company, CODESP) and the remarkably uniform tariffs charged by the newly qualified private sector port operators.

Disintegrating Consensus: Decades of past governments' divisive strategies made business consensus rare and unlikely to last. Business learned to take a reactiveadaptive short-term approach in its relations with State actors. While such tactics were necessary, given the policy shifts and shocks of the past two decades and the concentration of power in the Executive, - it also reduced business capacity to resist, based on principle. As one AEI leader noted, "Everybody is courageous when all is well [...] The first sign of trouble and all resistance breaks down. This makes maintaining solidarity an unrealizable goal" (interview in October 1997 in Rio de Janeiro). Corporatist federations find it difficult to focus on common positions, and conflicts of interest among directors and conflicting interests of members are the norm. Matters are further complicated by the fact that federations in different states sometimes oppose each other's positions. ${ }^{13}$ Not surprisingly, government and legislators usually receive a confused picture of business policy preferences. Brazilian business' Achilles heel is disunity.

Divergence of interests and competition among businesses are not unusual, but what is remarkable is that Brazilian business is unable to forge and then maintain a consensus, because of the strong incentives to yield to the temptation of particularist access to (often corrupt) bureaucrats who implement policies in a discretionary manner. Institutional arrangements, based on corporatism, State interventionism and a closed economy, augment business opportunities for rent-seeking and free-riding. This became obvious already in the early period of port reform, when the media noted the competitive behavior of port-users who made private agreements with unions to speed up the handling of their own cargoes at the expense of the collective decision to insist on the implementation of the new labor management regime. ${ }^{14}$ This type of free-rider behavior discredited any attempt to demonstrate longer-term business unity and solidarity on the port issue.

Later, two other groups of businesses demonstrated a more overt tendency to subvert reform implementation - maritime agents and manufacturers of tradeables in recently liberalized sectors. The former group actually benefited from high port costs because they were paid on a percentage of these, and the latter group historically tended to ignore port issues because they were irrelevant in their highly protected "captive" markets. During the policy formulation stage, the AEI managed to marginalize maritime agents and failed to devise any compensatory mechanism, thus

\footnotetext{
${ }^{13}$ For example, FIESP opposed a bill providing special incentives for the merchant marine and shipbuilders. In Rio de Janeiro, there was strong support for the bill reflecting the importance of shipbuilders in the Rio federation. Interviews in São Paulo in July 1994.

${ }^{14}$ See Tavares de Oliveira's articles in O Globo, 9 November 1995 and 3 October 1996.
} 
leaving this key group of port related businesses without any stake in successful reform implementation. This problem was compounded, when under the new legislation, many former maritime agents registered as port operators, thus underlining their lack of identification with the interests of port-users. Meanwhile, the second group passively went along with AEI's demands, perhaps not calculating the competitiveness impact of more efficient and cheaper ports on the price of imports in the domestic market. Moreover, during policy formulation, the emphasis was on increasing exports (liberalization had not yet led to a surge in imports), something that most businesses could agree on. However, the greater market liberalization and price stabilization from 1994 onwards enlarged the group of businesses unwilling to face additional competitive pressure from cheap and efficient ports.

Ultimately, AEI failed because business was disunited. Cooperation and consensus were practical as well as theoretical problems. A superficial consensus, once exposed, strengthened the hands of the opposition. It was superficial to the extent that it was a passive agreement to go along with AEI leaders' demands. ${ }^{15}$ What had been a strength during policy formulation (because it limited the number of participants in the policy arena and concentrated policy inputs), became a weakness in the policy implementation phase of reform (because most businessmen were not committed to AEI positions, and hence, uninterested in monitoring implementation). The fragile consensus broke down as soon as the diverse sub-sectors realized the differing impact of port reform on each of their businesses. Moreover, for most businesses, cargo volumes and values were not sufficiently large to make it worthwhile to hold out for reform, and they preferred to yield to the demands of port unions and port operators to ensure timely delivery of their goods.

Business played a central role in the implementation of the port modernization process, because in line with government policy, the law sought to minimize government involvement in ports. The private sector was given control not only over worker registration and nomination to work-teams, but was also given responsibility for undertaking investment and improving efficiency in port infrastructure and services via privatization of port operations. Thus, while port-users continued to struggle with high prices and inefficiency, port operators suddenly resisted reducing prices and investing in modernization. Both operators and ship owners were accused of cartel-like price setting. ${ }^{16}$

One important lesson for business was that the fighting spirit and the pro-reform network must be maintained until implementation is assured and complete. Businesspeople soon realized that reviving their former unity of purpose and action was a formidable task, and the reconstituted AEI, operating under the name Comissão Portos, was unable to achieve the same level of commitment and unity

\footnotetext{
15 One labour leader remarked on the "fictional and fabulous" nature of the business consensus, which "once unmasked could not protect business victories." (interview in October 1997 in Brasília).

16 A 1996 FIPE study found that the private sector was to blame for a large proportion of port inefficiency and high costs. It specifically noted the uniform price table of port operators in Santos port.
} 
among its members. All the same, AEI set a powerful example. In fact, business tried to build an AEI-style unified multi-associational and cross-sectoral platform around demands for constitutional reform. Jorge Gerdau was specifically invited to lead this effort, in an attempt to capitalize on his reputation as leader of the original AEI.

Business also learnt that consensus and unity were invaluable assets in a lobbying campaign. In 1996, Fernando Bezerra, president of CNI, called upon industry to present a united front to government and society:

"We feel the necessity of constructing unity in the industrial sector, which is not an easy task. Not that we are disunited, but the fact is that we are dispersed. Also the client-supplier relation can be conflictual. Hence, the need to create unity [...] We have a contribution to make that goes beyond our factories; we have a contribution to make to the economic, political and social development of our country." ${ }^{17}$

To summarize, in certain cases, business provided workers and bureaucrats, who have a vested interest $\mathrm{t}^{18}$ in the longevity of port service monopolies, with the ammunition to destroy hopes for an efficient and cost-effective port system. Although corporatism and disunity reinforce each other, there are signs of change. Firstly, globalization, liberalization and deregulation pose new challenges for business and promote more active participation in the policy debate.

Secondly, democratization altered the parameters of acceptable business lobbying and interaction with State actors. The means employed to influence outcomes became as important as the composition of business demands. Currently, lobbying as well as policy outputs are evaluated in terms of their normative content, and demands must be couched in terms of the public interest to achieve legitimacy in the eyes of society. Moreover, the State no longer possesses the authoritarian capacity to enforce implementation, and must negotiate with interest groups so that policy intentions match policy outcomes.

Thirdly, whereas in the past, government ministers in effect "bought the conscience" of federation directors by handing out subsidies and privileges, the new environment forces the federations and businesses to look within themselves for profit and success. Many businesses have committed substantial resources to modernizing and improving the quality of their output and the productivity of their factories. The new business elite is drawn from firms that are winners in a competitive environment, and are unlikely to allow reactionary corporatist practices to jeopardize the success of their investments. AEI's achievements give business hope

\footnotetext{
${ }^{17}$ Quoted in the O Estado de S. Paulo, 19 May 1996.

18 Anti-reform State actors include some members of the port administrations, transport and labour ministries, customs clearance officials, state and municipal governments tied to port interests, legislators with strong port constituencies, and even some members of the Navy.
} 
that corporatism and disunity can be overcome, and that institutions and behavior respond to changing circumstances.

\section{OVERCOMING BUSINESS DIFFICULTIES}

Analysis of business difficulties in influencing and sustaining the pressure for policy reform raises the issue of whether the rigid structures of corporatism are compatible with liberalization and modernization. Why does corporatism inhibit progress? What are the modifications to business-State relations suggested by AEI's experience? While the policy formulation period of AEI success suggests solutions that move in opposite directions, policy implementation appears to depend on pressure exerted through a long-lasting stable closed network with a stake in reform success. Early stages of the reform process show that on the one hand, at the sectoral level, business needs to overcome fragmentation and weak policy formulation capacity by constructing a close-knit stable policy network. On the other hand, at the aggregate (class) level, business must overcome disunity and problems of collective action by building a broad peak association structure that can aggregate and articulate interests at the national level to press home the importance of a particular measure for the general interest of business. Later stages of the reform process rely on the engagement of a specific group, coalition or network prepared to play an active role in monitoring implementation with only tacit support at the aggregate level. The following analysis demonstrates that these solutions are complementary in character, although they might appear to be contradictory.

Liberalization and globalization obliged business to open its eyes to the longlasting hold of the port unions on port policy (the port labor regime dates back to the 1930s), and exposed the weakness of business networks in the port sector. Business understood that the politicization of the port issue was necessary to force a complete change in the structure and institutions of the port sector, to overthrow the established rules of the game and consultation mechanisms. It needed to muscle its way into the comfortable relations within the corporatist network between bureaucrats and labor in the sector. The competence and perseverance of the AEI lobby bore fruit in terms of business impact on policy output. But the lack of a stable policy community jeopardized business' ability to match policy intentions with outcomes.

The preceding sections demonstrated first, how business organized itself and built a network around the issue of port institutional modernization, and then, how corporatism impacted business attitudes and actions, fragmented business demands and blocked reform. The success of the AEI, as a network that lies somewhere between issue network and policy community, suggests the utility of looking into the option that policy network analysis offers for the adaptation of corporatist institutions to a modernizing reform agenda. This section presents a brief description of policy networks and contrasts them with corporatist networks in Brazil. Since this article focuses on business networks, it will analyze the difference be- 
tween policy networks and bureaucratic rings (the specific form business corporatist networks take), and locate the AEI within the analysis.

Although there are a few exceptions, notably Peter Evans ${ }^{19}$, the general body of network literature does not deal with developing economies. Yet here the importance of networks, personal and institutional, cannot be overlooked. Brazil is a case in point. In a country where economic groups are marginalized from strategic decision-making, businesspeople are forced to develop alternate, informal channels of access to State actors, usually to the relevant bureaucratic agency, entrusted with the application of rules and the allocation of resources, in the sector. Thus, business associations develop into sector-specific nuclei with solidarity to particular agencies. While options under authoritarian regimes were limited, democratization provided business with the opportunities and appropriate channels to attract the attention of the executive and legislature. If it managed to play its cards right, it would benefit from the establishment of policy communities.

Jordan and Richardson developed the idea of a policy community as a closed and close group with frequent interaction and shared values, where State actors tended to consult certain groups, and limited access to others. The relationship was not zero-sum, since a well-resourced State could increase its autonomy, and extend its infrastructural power, through policy networks. The network approach also emphasized the difficulty in drawing a stark dichotomy between State and civil society. After all, State actors are members of society.

Table VI: Policy Network Analysis

\begin{tabular}{lll}
\hline Dimension & Policy Community & Issue network \\
\hline Membership & Limited numbers; some exclusion & Large numbers \\
\hline Type of Interest & Economic/Professional & Wide range of interests \\
\hline Frequency of Interaction & Frequent; high quality & Contact fluctuates \\
\hline Continuity & $\begin{array}{l}\text { Membership, values, and outcomes } \\
\text { are persistent }\end{array}$ & Fluctuating access \\
\hline Consensus & Participants share basic values & $\begin{array}{l}\text { Some agreement; some } \\
\text { conflict }\end{array}$ \\
\hline Power & Positive-sum; balance & Zero-sum; unequal \\
\hline
\end{tabular}

Source: Smith (1993); Marsh \& Rhodes (1992)

Policy networks can range from a limited exchange of information to institutionalization of the group within the policy process; from closed and close-knit

\footnotetext{
${ }^{19}$ Evans (1995) developed the concept of "embedded autonomy" to explain the network of social ties that binds the State to society and provides the institutional channels for policy formulation in developing countries like Brazil, India and Korea.
} 
policy communities to open issue networks as described in Table VI. ${ }^{20}$ In a policy community there is a high degree of consensus on policy aims, rules of the game, as well as the range of problems and potential solutions to them. Policy communities create stability in the policy arena, since they de-politicize the issue. In an issue network the reverse applies - there is no consensus between groups on policy aims, a large number of groups and government departments may be involved, increasingly politicizing the issue and impeding stable and lasting solutions. Finally, policy networks should not be confused with corporatist networks, where policy consensus is irrelevant because of the State's agenda setting powers, and centralization of decisionmaking means power is shared unequally (although it can be positive-sum). Moreover, interaction is ad hoc, personalistic, and often takes place in a controlled undemocratic context.

Already, Schmitter (1971) noted the paradox of the highly formal nature of corporate interest groups that contrasted with the intimate, interpersonal and largely unrecorded manner of conducting business-State relations. For most of the past 60 years, business normally dealt with the government via narrow, decentralized, ad hoc networks, or what Cardoso called "bureaucratic rings". When in the early 1980s, Minister Delfim Netto phased out official representation of business in government councils, businesspeople were forced to turn to the middle-level bureaucracy, and to create informal links with them to influence policy implementation. Thus, bureaucratic spheres emerged, drawing in bureaucratic allies of business to defend the latter's economic interests (Cardoso, 1986). However, as Schneider notes, industrialists only had limited success at perforating bureaucratic insulation, and in general, "industrialists have never modeled lasting paths of access to policy-making circles.” (Schneider, 1991).

Bureaucratic rings should not be seen as the equivalent of policy communities. They differ on a number of important aspects. First, bureaucratic rings were targeted at the regulatory and implementation phase of policy; a policy community's objective is to influence policy-formulation and monitor implementation. Second, business approached State actors in bureaucratic rings as a supplicant, in the expectation of some reward; in a policy community, the State consults business at every stage, and business is an almost equal partner in determining the policy agenda and policy output. Third, bureaucratic rings were ad hoc groups, based on personal relations and interaction; a policy community is long lasting with frequent interaction based on semi-institutionalized relations (i.e. a policy community does not rely on exclusively personal connections and preferences, and exists beyond the terms of office of individual ministers, bureaucrats and group leaders). Fourth, bureaucratic rings were often secretive and did not seek exposure in the media, making them most successful in a non-democratic setting; a policy community

\footnotetext{
${ }^{20}$ Marsh and Rhodes note that networks can be arranged on a continuum, ranging from policy community to issue network.
} 
operates in a democratic context and relies on the media to communicate its views to society.

Table VII: Types of Policy Networks in Brazil

\begin{tabular}{lll}
\hline Dimension & Policy Community & Bureaucratic Ring \\
\hline $\begin{array}{l}\text { State Actor } \\
\text { Participation }\end{array}$ & High-level bureaucrats; Ministers & Middle- bureaucrats; rarely ministers \\
Target & Policy formulation \& implementation & Policy regulation \& implementation \\
Interaction & Frequent; semi-institutionalized & Ad hoc; personal \\
Continuity & Membership, values, outcomes persistent & Fluctuating access and outcomes \\
Consensus & Participants share basic values & Not directly relevant \\
Power & Positive-sum; balance & Positive-sum; unequal \\
Media & Free and democratic & Controlled and censored \\
\hline
\end{tabular}

Source: author's own elaboration.

The key concern in a democratic setting is the State's need to retain autonomy and prevent its agent's closeness from degenerating into rent-seeking coalitions, that is, bureaucratic rings are seen as unacceptable forms of business-State interaction. Evans (1995) found that industrial transformation thrived, where the State successfully combined an embedded bureaucracy with an autonomous State and where business-State networks helped improve policy inputs and outcomes. One of the main benefits of "embedded autonomy" was that it helped States resolve the contradiction between credibility and flexibility in a reform project. It allowed bureaucrats to make adjustments to reform packages, without losing credibility. The key was communication with business networks that learned to understand the signals and intentions of State actors. Reformers need societal support.

The juggling act that demonstrated firmness of intentions and flexibility of actions required strong institutions and lines of communication between the key participants in the political economy. In this sense, policy communities assist in achieving a close match between policy intentions and outcomes due to their ability to maintain open lines of communication between State and society. In Brazil, repeated economic crises forced policy-makers to change direction on a number of occasions, but limited dialogue between business and State increased uncertainty and complicated implementation. Moreover, fragile institutions, at both the State and associational levels, made it difficult to organize support for reform programs. The only strong institution, corporatism, hindered market-oriented reform, and hampered the formation of new networks geared towards structural reform.

The established corporatist network in ports had the tenacity and capacity to block implementation of Law 8.630/93. Union leaders, interviewed in 1994 more than a year after adoption of the law, could proudly claim that "so far we have lost nothing; nothing has changed". There is no better testimony to demonstrate the 
effectiveness of the port corporate network in maintaining the status quo than the survival of the port union monopoly in nominating daily-hire labor to work teams aboard ships. ${ }^{21}$ It also illustrates the dimension of the problem facing the nascent AEI, a new network forced to contend with a sixty-year old entrenched one.

AEI's relations to State actors resembled an issue network in terms of frequency of interaction, continuity and consensus. In terms of the other dimensions in Table VII, i.e. membership, type of interest and power, it resembled a policy community. Its trump card was its essentially democratic and open character. At the policy formulation stage, AEI could have been described as a fledgling policy community, but it failed to cash in on this advantage. Surprisingly, business leaders initially failed to recognize the importance of establishing a long-term close-knit policy community to monitor reform implementation, reducing AEI at best to an issue network, suffering from the associated weaknesses of such networks.

Although corporatist networks and policy communities are based on very different principles, their essential structure of stable relations between State and nonState actors are sufficiently similar to allow incremental adjustments to corporatist institutions, democratizing them, to eventually establish policy communities. The research project found that corporatist networks could serve as the building blocks for the development of democratic policy networks via the restructuring and consolidation of the former into policy communities. The latter provide groups with new opportunities to form constructive democratic alliances that collaborate with reform efforts and offer a feasible option for the evolution of corporatism.

However, policy communities do have their limitations. Firstly, the legacy of corporatism in Brazil: replacing corporatist institutional arrangements with their emphasis on the top-down approach to interest representation with policy communities with their emphasis on a shared role for all participants in decision-making is unlikely to be seamless. Secondly, impatient reformers might not be willing to wait for the gradual development of policy communities. Moreover, policy communities in general can have the distinct disadvantage of discouraging innovative approaches and radical solutions to policy problems, because of their emphasis on institutionalized non-conflictual relations within the community (it is in this sense that most established networks tend to be pro status quo).

It may not be possible to create efficient policy communities in the short run, but these networks present a better medium-term opportunity for business to influence policy outcomes than do purely pluralist options. There is a certain appeal to the logic of adaptive efficiency, where the institutional structure changes via incremental adjustments to the formal rules and the informal constraints and norms of behavior, avoiding abrupt breaks in the historical evolution of these institutions.

\footnotetext{
${ }^{21}$ In 1998, Salvador became the first port to allow the business controlled OGMO to nominate workteams. In February 2001, eight years after the law came into effect, unions in most ports, including Santos, retained the right to nominate workers.
} 


\section{CONCLUSION}

The port reform issue underlined the erosion of traditional business-State relations. Democratization and socio-economic modernization changed the political and economic context within which business operated, and challenged the existing patterns of interest aggregation and representation. First, democratization increased the importance of transparency in policy-making and implementation, and of augmenting the role of labor to prevent business capture of bureaucratic agencies (on some occasions, as in ports, the reverse applied). Second, democratization changed the position of bureaucrats, as business networks or individual firms' ties within bureaucratic rings were diluted. Third, labor became more assertive with socioeconomic modernization. It was quick to form a number of competing labor peak associations to bring their collective interests to bear on policy-makers and to enhance their bargaining power with employers. Fourth, the heightened complexity of economic policy-making and the reduced capacity of the State enhanced the role of business associations in policy implementation. Fifth, the younger generation of business leaders accepted the need for an open and democratic approach to policymakers and other State actors. It is in this modern business class that there originates the strong possibility of moving beyond rent-seeking coalitions and individualistic forms of business-State interaction.

It is worth highlighting the benefits of applying an eclectic mix of approaches and theories to explain business behavior. Although the port reform process is a very specific and narrow area of study, the case is rich with suggestions for institutional and structural reforms in other issue areas in Brazil. It demonstrated the consequences of overlooking the influence and entrenched position of prevalent corporatist networks. The wide-ranging impact of port reform on the economy as a whole and the way it involved all participants in the political process provide useful insight into how interests can successfully approach the question of institutional reform.

To summarize, this article analyzed the impact of corporatism and the difficulty of institutional change; it then used policy network analysis to suggest the possible direction of institutional modernization. The dynamic element in the evolutionary process was explained via the logic of collective action model, which involves evaluating the conditions required for business to organize and co-operate in its demands for institutional change. AEI closely reflects the theoretical explanations for the evolution of Brazilian institutions and interest groups. It constructed unity from corporatist fragmentation, after an active group of winners managed to organize collective action along the lines of policy networks.

Although AEI managed to put in place a successful issue network, it failed to establish a policy community to replace the old-style corporatist network in ports. This failure touches on a very important question in the academic debate around institutional change: what accounts for the survival of institutions that consistently under-perform over long periods of time? The paper provided some insight into the nature of vested interests, and how reformers find it extremely difficult to 
shift the former's focus from redistributive to productive activities. Another obstacle is State capacity, which this article does not elaborate on.

The slow and costly reform process, weighed down by the legacy of corporatist inertia as described in this article, is perhaps the least efficient approach to reform, but Brazil is yet to demonstrate political commitment and economic backing for a radical, clean-cut break away from past institutional structures and procedures. The question of constructing a lasting pro-reform consensus reappears at numerous junctures, but so far institutions and the political bargaining process have been unable to prevent the consensus from disintegrating. While some attempts were made at establishing policy networks to steer the reform process, these fell short of entrenching themselves, were unable to rationalize institutional modernization, and thus failed to maximize the social and economic benefits of the reform process.

To conclude, the port reform process might be an extreme and stark example of business lobbying and the legacy of corporatism, but it served as an excellent means for laying bare the tendencies exhibited by and hindering the Brazilian institutional and structural reform process. The main value of the analysis lies in the fact that port reform can be linked to the broader reform agenda in Brazil and Latin America. The port reform process exposed all the weaknesses of Brazilian business, but also demonstrated that business could overcome these weaknesses. The key lessons were that strength and influence were the fruits of unity and consensus among business people, and corporatist institutions could evolve into policy networks based on pluralist and democratic approaches to business-State relations. AEI showed business that its Achilles heel could be overcome, and perhaps cured.

\section{INTERVIEWEES}

\section{Business}

Agamenon Magalhães Melo, Director, Companhia Agrícola Massangano

Aldebert de Queiroz, Director, AEA; FIESP; ANFAVEA

Carlo Barbieri Filho, Grupo Barbieri; Vice-President of Brazilian Trading Companies Assoc.; FCESP

Daniel Ioschpe, Vice-President of Board of Directors, Companhia Ioschpe; FIERGS

Emerson Kapaz, ABRINQ; also São Paulo State Secretary for Science, Technology and Economic Development

Farid Murad, President of Maynard Comércio Internacional Ltda.; Director of ACSP Guilherme Noschese, Noschese Consultaría; Deliberative Council of ACSP; AJEESP; ABINEE Jairo Cupertino, Executive Vice-President of Investimentos Itaú S.A.

João Emílio Freire, ABTP; Comissão Portos;

José Candido Senna, Executive Director, ConTrader; ACSP

José Carlos Mayer, Head, Foreign Trade Department, FIESP

José Ermirio de Moraes, Votorantim; President Emeritus of FIESP; Honorary President of SNIC; others 
José Luis de Freitas Valle, Director of Foreign Trade Department, FIESP; CAP-Santos Representative

José Mario P. do Rio Branco, Political Action Coordinator, FIESP

José Ribamar Brasil Chehebe, Secretary of Technology and Primary Materials, IBS

José Ulysses V. Coutinho, Director of Cotia Trading S.A.; Director of AEB, ABECE, ACSP, ACRJ;

Advisor to FIESP, FCESP, CNI, CNC, ADEBIM, FAESP

Joseph Couri, President of SIMPI

Juan Clinton Llerena, Advisor to AEB, ABTP and ACRJ; CAP-Rio de Janeiro Representative

Luiz Augusto de Camargo Opice, Managing Director of Armazéns Gerais Columbia S.A.

Mario Amato, President of CNI; ex-President of FIESP

Mario Martin Schenk, Executive Secretary of FMP/RS

Miguel Pires, Operations Director, Navegação Guarita and Interportos; FIERGS; FMP/RS

Nelson L. Carlini, Wilson Sons Ltda.

Oscar Bay Filho, Executive, International Department of FIERGS

Osmar Luis Rebelo de Oliveira, President of ABTP

Paulo Duhá, FMP/RS

Paulo Caldeira de Freitas, General Manager, Banco Itaú S.A.

Paulo Hegg, Director, Tabaex; Foreign Trade Advisor in ACSP

Paulo Perlott Ramos, Export Director, Grupo Gerdau

Pedro Eberhardt, Managing Director of Indústrias Arteb and others; ex-President of SINDI-

PECAS;

Vice-President of FENABRAVE; Advisor to IEDI; SINDIPLAST

Renato Abucham, Vice-President of Ecoban Finance ltd.; CIOI at ACSP

Sergio Azeredo, President of the Association of Brazilian Marble and Granite Industry);

CIESP Thales Robin Silva, Director of Nautilus Agência Marítima Ltda.

Wilen Mantelli, Vice-President of ABTP; Coordinator of FMP/RS; FIERGS

Yaracy F. Rodrigues, Foreign Trade Department, FIESP

\section{Labour Leaders}

Abelardo Whickam Fernandes, President of National Federation of Stevedores

Adeildo Paraiso da Silva, President of Union of Stevedores, Recife

Fernando Marcelo Cavalcante da Silva, ex-President of Checkers Union, Recife and director of FENCCOVIB

José Peres Cesar, President of National Federation of Dockworkers

José Tarciso Florentino da Silva, President of Checkers Union, Santos

Mário Ferreira da Silva, Secretary of Union of Stevedores, Recife

Mayo Uruguaio Machado Fernandes, President of Checkers Union, Rio de Janeiro;

Vice-President of CONTTMAF

Oswaldo Nunes, President of Checkers Union, Recife

Rubens Fortes Antonio, National Federation of Dockworkers; CAP-Santos Representative

\section{Port Administrators}

Patricio Alvaro, Operations Manager, CODESP, Santos 
Helio Burgos, Judicial Sector, Port of Recife

João Teixeira, Operations Manager, DEPREC, Porto Alegre Ruth Alberquerque, Chief of Studies and Budget, Port of Recife

\section{Legislators (Members of the National Congress)}

Angela Amin (PPB-SC), Deputy

Antonio Delfim Netto (PPB-SP), Deputy; former Minister of Finance and of Planning

Carlos Santana (PT-RJ), Deputy

Gaston Righi (PTB-SP), Deputy

José Carlos Aleluia (PFL-BA), Deputy; Relator of final version of PL08/91, later Law 8.630/93

José Reinaldo Tavares (PFL-MA), Deputy; Rapporteur of earlier version of PL08/91; ex-Minister of Transport

Luis Roberto Ponte (PMDB-RS), Deputy; Presient of Special Commission for PL08/91;

Minister, Chef da Casa Civil under Sarney

Nelson Marquezelli (PTB-SP), Deputy; Director of FAESP; President of ASSOCITRUS

Nabor Junior (PMDB-AC), Senator; Senate Infrastructure Commission in 1992-93; ex-Governor of Acre

\section{Other State Actors}

Antonio Carlos Firminio, Advisor, Chamber Commission for Transport

Antonio Carlos Pojo do Rego, Senate Technical Advisor for PSDB Leadership

Gentil Mendonca Filho, Ministry of Labor Representative at GEMPO

Geraldo Viera, Ministry of Transport (1990-1992)

Eriksom Teixeira Lima, Economist, Transport Infrastructure Sector, BNDES; Director, Institute of Economists of Rio de Janeiro (IERJ)

José Ribamar Miranda Dias, Admiral; Executive Secretary of GEMPO; Navy Ministry

José Rodrigues, Advisor on Port Issues, Santos Municipality

Luciano Otávio Marques de Velasco, Manager, Transport Infrastructure Sector, BNDES

Paulo Afonso Lopes Cabezon, Legislative Advisor, Chamber of Deputies

Paulo Loquercio, Advisor to PMDB in Congress

Robson Tavares Dutra, Labor Court Judge; lawyer for FENCOVIB (1983-93)

Rubens Barbosa, Brazilian Ambassador to the United Kingdom

Others

Carlos Tavares de Oliveira, Journalist (mainly O Globo), Foreign Trade Advisor to CNC Charles Smith, Labor Issues Specialist, General Consulate of the USA in São Paulo

Derek Smith, Development Manager, Southampton Container Terminals

Mara Lemos, Journalist, Commodities Correspondent, Dow Jones News Service in São Paulo

\section{REFERENCES}

BOSCHI, Renato R. (ed) (1991) Corporativismo e Desigualdade. Editora Rio Fundo, Rio de Janeiro.

CARDOSO, Fernando Henrique (1986) "Entrepreneurs and the Transition Process", in O'Donnel, Guillermo and Laurence Whitehead, eds., Transitions from Authoritarian Rule, Comparative Perspectives, Johns Hopkins University Press, Baltimore. 
CAWSON, Alan (1986) Corporatism and Political Theory, Blackwell, Oxford.

COHEN, Youssef (1989) The Manipulation of Consent: the State and Working-class Consciousness in Brazil, University of Pittsburgh Press, Pittsburgh.

DINIZ, Eli; ed. (1993) Empresários e Modernização Econômica: Brasil Anos 90, Editora UFSC, Florianópolis.

DINIZ, Eli (1997) Crise, Reforma do Estado, e Governabilidade, Fundação Getulio Vargas, Rio de Janeiro.

DINIZ, Eli and Renato R. BOSCHI (1978) Empresariado Nacional e Estado no Brasil, Forense Universitária, Rio de Janeiro.

DINIZ, Eli, Renato BOSCHI and Roberto LESSA (1989) Modernização e Consolidação Democrática no Brasil: Dilemas da Nova República, Editora Vértice, São Paulo.

EVANS, Peter (1979) The Alliance of Multinational, State and Local Capital in Brazil, Princeton University Press, Princeton.

EVANS, Peter (1995) Embedded Autonomy: States and Industrial Transformation, Princeton University Press, Princeton.

FARO, Luiz César and Ricardo BUENO, eds. (1994) Brasil: Propostas de Reforma, Editora Paz e Terra, São Paulo.

FRIEDEN, Jeffry A. (1991) Debt, Development and Democracy: Modern Political Economy and Latin America, 1965-1985, Princeton University Press, Princeton.

GEDDES, Barbara J. (1986) Economic Development as a Collective Action Problem: Individual Interests and Innovation in Brazil, Ph.D. dissertation University of California, Berkeley, 1986.

MARQUES DE VELASCO, Luciano Otávio, and Eriksom TEIXEIRA LIMA (1996) "O Sistema Portuário Brasileiro", Revista do BNDES, December 1996.

MARSH, David and R.A.W. RHODES, eds. (1992) Policy Networks in British Government, Clarendon Press, Oxford, 1992.

MAXFIELD, Sylvia and Ben Ross SCHNEIDER, eds. (1997) Business and the State in Developing Countries. Cornell University Press, Ithaca.

MOE, Terry M. (1980) The Organization of Interests, University of Chicago Press, Chicago.

MOREIRA, Mauricio Mesquita (1995) Industrialization, Trade and Market Failures: the Role of Government Intervention in Brazil and South Korea, St. Martins Press, New York.

NORTH, Douglass C. (1990) Institutions, Institutional Change and Economic Performance, Cambridge University Press, Cambridge.

O’DONNELL, Guillermo, Philippe SCHMITTER and Laurence WHITEHEAD, eds. (1986) Transitions from Authoritarian Rule: Prospects for Democracy, Johns Hopkins UnivPress, Baltimore.

OLSON, Mancur (1971) The Logic of Collective Action: Public Goods and the Theory of Groups, Harvard University Press, Cambridge, 1971.

SCHMITTER, Philippe C. (1974) “Still the Century of Corporatism?”, Review of Politics, v. 36.

SCHMITTER, Philippe C. (1971) Interest Conflict and Political Change in Brazil, Stanford University Press, Stanford.

SCHMITTER, Philippe C. and G. LEMBRUCH, eds (1979) Trends toward Corporatist Intermediation, SAGE, London, 1979.

SCHNEIDER, Ben Ross (1997) Helpless Giants: Big Business and Constitutional Reform in Brazil, Paper at ILAS Brazil Conference, London, 1997.

SILVA, Francisco C. de Morais (1994) Direito Portuário: a Modernização dos Portos Brasileiros, Lei no 8.630, Del Rey Editora, Belo Horizonte, 1994.

SMITH, Martin J. (1993) Pressure, Power and Policy: State Autonomy and Policy Networks in Britain and the United States, Harvester Wheatsheaf Press, New York.

TAVARES DE ALMEIDA, Maria Hermínia (1989) “Direitos Sociais, Organização de Interesses, e Corporativismo no Brasil”, Novos Estudos 25, October 1989. 